\title{
The AEgean IMAGINARIUM: Selected Stereotypes and Associations Connected With the Aegean Sea and Its Islands in Roman Literature in the PERIOD OF THE PRINCIPATE*
}

\author{
Bartosz Jan Kołoczek \\ iD http:/orcid.org/0000-0003-1401-0093 \\ Jagiellonian University in Kraków
}

\begin{abstract}
This article is devoted to the rarely addressed problem of Roman stereotypes and associations connected with the Aegean Sea and its islands in the works of Roman authors in the first three centuries of the Empire. The image of the Aegean islands in the Roman literature was somewhat incongruously compressed into contradictory visions: islands of plenty, desolate prisons, always located far from Italy, surrounded by the terrifying marine element. The positive associations stemmed from previous cultural contacts between the Aegean and Rome: the Romans admired the supposedly more developed Greek civilisation (their awe sometimes underpinned by ostensible disparagement), whereas their elites enjoyed their Aegean tours and reminisced about past glories of Rhodes and Athens. The negative associations came from the islands' desolation and insignificance; the imperial authors, associating the Aegean islets with exile spots, borrowed such motifs from classical and Hellenistic Greek predecessors. The Aegean Sea, ever-present in the rich Greek mythical imaginarium, inspired writers interested in myth and folklore; other writers associated islands with excellent crops and products, renowned and valued across the Empire.
\end{abstract}

Keywords: Aegean Sea, Aegean islands, Roman literature, Roman poetry.

For the Aegean region under the Roman rule, the end of the civil wars, the twilight of the Republic and Octavian's ascendance did not bring much political stabilisation; ${ }^{1}$ however, it did remove the region from the spotlight of the Roman politics, with the islands becoming yet another peripheral region in the sprawling Empire. In light of such a change, it is justifiable to ask whether these changes impacted the manner in which the Romans

* The present paper was prepared thanks to the grant from the National Science Centre: UMO-2012/7/B/ HS3/03455.

1 Pawlak 2016, 211. 
perceived the Aegean Sea and its islands. Another question is whether the Romans had a collective stereotyped image of the Aegean, since the fragmented region divided into numerous minor islands and poleis, with observable differences among them. The emergence of certain literary topoi associated with the Aegean and their deployment, traceable thanks to surviving imperial literary works, gives us an opportunity to consider the Roman rule over the Aegean Sea from a less obvious but still significant point of view, enriching our understanding of the Roman rule over this part of the world and revealing Roman attitudes towards lands admired for their ancient culture, yet perceptibly foreign to a Roman eye. A thorough appraisal of all associations related to the Aegean Sea and its islands in Roman literature would exceed the limits of this article, so I intend to focus on selected - in my opinion the most representative-Aegean motifs in the works of Roman authors in the first three centuries of the Empire. ${ }^{2}$

The first Roman stereotype on the Aegean $\mathrm{Sea}^{3}$ considered in this article comes from the intriguing idea that its name derives from boiling water from which emerge small goat-shaped rocks. Found in Marcus Terentius Varro's treaty De lingua Latina (published in the Republican times), this image had a perceptible influence on Roman writers of the following period:

Pacui: "Linqui in Aegeo fretu." Dictum fretum ab similitudine ferventis aquae, quod in fretum saepe concurrat aestus atque effervescat. Aegeum dictum ab insulis, quod in eo mari scopuli in pelago vocantur ab similitudine caprarum aeges. ${ }^{5}$

The origin of the name of the Aegean, Greece's most important sea, attracted the attention of Greek writers from the archaic period onwards. Older aetiological myths derived the name from Aegeus, Aegaeon, or the city of Aegae, whereas Hesychius of Alexandria (5th/6th c. CE) linguistically derived the name of the Aegean from one of Greek terms referring to waves ( $\alpha \tilde{\gamma} \gamma \varepsilon \varsigma$ - aiges — notably, a homophone of 'goats') and shores

2 This article is a modified and expanded version of an earlier work in Polish: Burzliwe morze, spokojne wyspy. Wizja Morza Egejskiego w literaturze rzymskiej okresu pryncypatu, in: M. Pawlak, M. Piegdoń, B. Kołoczek (eds.), Fretum Aegeum. Rzym a Wyspy Egejskie od II w. p.n.e. do III w. n.e., (Aigaion, vol. II), Kraków 2016, 137-177. The topic of Roman associations with the Aegean Islands has been neglected in literature, save the synoptic work on the Roman approach to the islands (Borca 2000).

3 The Aegean Sea in Roman literature also appeared under other names (also as references to its constituent parts), as the Myrtoan, Carpathian, Icarian, Cretan, Macedonian, Thracian or even Greek Sea; these names, apart from the strictly mythological context (Icarian Sea), generally referred to the exact geographical location of the sea in question. See e.g. Pliny, NH 4.29, 51, 71.

4 Pac. Trag. Rom. Frag. 420 Ribbeck $^{3}$; R.O.L. II 306-307 Warmington. Unfortunately, we do not know whether the cited fragment referred to Ariadne, abandoned by Theseus on the shores of Naxos (on this topic, see especially Manioti 2017; cf. below), to Philoctetes, left on Lemnos by the Achaeans sailing to Troy, or to somebody else. Denoting the sea by this specific term (fretum), Pacuvius (also a renowned painter) probably wanted to convey the danger and wildness of the element in which his protagonist found himself or, perhaps, also his feeling of loneliness (elements subsequently emphasised in later Roman depictions of this region), but we can hardly conclude that Pacuvius already foreshadowed these elements of the Aegean imagery in his poetry.

5 Varro, De ling. Lat. 7.22: "In the verse of Pacuvius, 'To be forsaken in the Aegean strait', fretum 'strait' is named from the likeness to fervens 'boiling' water, because the tide often dashes into a strait and boils up. The Aegean is named from the islands, because in this sea the craggy islands in the open water are called aeges 'goats', from their likeness to she-goats"' (trans. by R. G. Kent, LCL). 


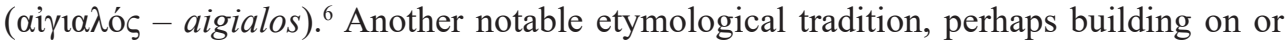
alluding to the homophonic association between goats and waves, appears in a work by Varro, who as the first author in the recorded tradition clearly and directly associated the Aegean islands with goats. It is difficult to say whether Varro made the connection or borrowed it from some other lost work. ${ }^{7}$ Certainly, Varro took pleasure in painting the vision of the rolling Aegean waves scattered with small white rocks; his commentary on Pacuvius' use of fretum, which he derives from boiling water, shows that he must have found this etymology convincing.

A similar explanation for the Greek name of the Aegean Sea appears over one hundred years later in Book IV of Pliny the Elder's Natural History, who mentions Varro as one of his sources for this information. Nevertheless, we can hardly speak of direct inspiration, because Pliny's account derives the sea's name not from the poetic vision of goat-like white islands emerging from its swell but from a reference to a single, rather insignificant (although also goat-shaped) rock named Aex. ${ }^{8}$ Unfortunately, it is impossible to establish whether Pliny emended Varro's etymology with his own invention, attempted to rationalise Varro's poeticised account, or followed another author, perhaps unmentioned in the index; however, since Pliny relayed the image of the Aegean dotted with goat-like islets (as did Solinus in the incredibly popular Collectanea rerum memorabilium two centuries later), it appears that this poetic vision remained alluring for subsequent writers.

The caprine imagery linked to the Aegean islands by Varro and later encyclopaedists did not, it seems, have any emotional underpinning, being based merely on visual and aesthetic associations. This observation will have relevance in regard to other connotations attached to inhospitable Aegean scopuli, places of exile in the imperial period. Nonetheless, let us first consider Varro's second image, the danger-ridden strait - fretum Aegeum - and its reception in works by later writers, as it underpins the entirety of Roman stereotypes about the Aegean and its islands.

The topos of the Aegean Sea as an inhospitable and remote land, somewhat discernible already in the fragment of Pacuvius' poetry cited by Varro, became particularly popular with Augustan poets. It was already present in Quintus Horatius Flaccus' (commonly known as Horace) Carmina, first published in $23 \mathrm{BC}$ :

Otium divos rogat in patenti / prensus Aegaeo, simul atra nubes / condidit lunam neque certa fulgent / sidera nautis; otium bello furiosa Thrace, / otium Medi pharetra decori, / Grosphe, non

6 Hesych., $\alpha 1679,1700$ Latte. For more information on this topic, see Fowler 1988, 99-102.

7 Book VII of De lingua Latina is, unfortunately, the only one which still lacks a separate historical and literary commentary. Consider, however, the recently issued linguistic commentary to the whole De lingua Latina by W. D. C. de Melo 2019 (about Ling. Lat. 7.22, p. 924-925).

8 See Pliny, NH 4.51: Aegaeo mari nomen dedit scopulus inter Tenedum et Chium verius quam insula, Aex nomine a specie caprae, quae ita Graecis appellatur, repente e medio mari exiliens. cernunt eum ab dextera parte Antandrum navigantes ab Achaia, dirum ac pestiferum ("The Aegean Sea takes its name from an island, or more truly a rock suddenly springing out of the middle of the sea, between Tenos and Chios, named Aex from its resemblance to a she-goat - $\alpha i \xi$ being the Greek word for the animal. In sailing from Achaia to Antandros, this rock is sighted on the starboard side, and it is a sinister threat of disaster"; trans. by H. Rackham, LCL); cf. Solin. 11.2: id quoniam visentibus procul caprae simile creditur, quam Graeci aega nuncupant, Aegaeus sinus dictus. 
gemmis neque purpura / venale neque auro. ... vivitur parvo bene, cui paternum / splendet in mensa tenui salinum / nec levis somnos timor aut cupido / sordidus aufert. ${ }^{9}$

The Aegean Sea, juxtaposed by Horace with Thrace and Media, i.e. utterly barbarian lands, connotes a daring life focused on bold yet uncertain ventures, adventures and travels. The author does not doubt the attractiveness of the region, quite the oppositestresses its riches and prestige they can bring (in a later version, the poet mentions treasure and a consul's lictor). Nevertheless, peculiarly for such an Epicurean poem, Horace concludes that the effort to master this treacherous sea is not worth the long, ${ }^{10}$ perilous journey. ${ }^{11}$

Similar and related associations with the Aegean appear in one of the poetic letters published by Horace two years later, in which the lyrical subject mocks a man named Bullatius, who set out on a dangerous journey to see rich Egyptian towns, preferring this kind of adventure over peaceful rest in front of a fireplace in Rome:

Quid tibi visa Chios, Bullati, notaque Lesbos, / quid concinna Samos, quid Croesi regia Sardis, / Zmyrna quid et Colophon? Maiora minorave fama, / cunctane prae Campo et Tiberino flumine sordent? ... nec si te validus iactaverit Auster in alto, / idcirco navem trans Aegaeum mare vendas. / Incolumi Rhodos et Mytilene pulchra facit quod / paenula solstitio, campestre nivalibus auris, / per brumam Tiberis, Sextili mense caminus. / Dum licet ac voltum servat Fortuna benignum, / Romae laudetur Samos et Chios et Rhodos absens. ${ }^{12}$

Evidently, cities of the Aegean under Augustus - associated with opulence, culture and beauty, ever-attractive to Roman tourists, such as Bullatius, anonymous to us today ${ }^{13}$ — no longer appealed to the Roman cultural elite of the early Empire, who suc-

9 Hor. Carm. 2.16.1-8, 13-16: "O Peace! implores the mariner of the gods / when he is overtaken on the broad Aegean / by a black tempest shrouding the moon, / and the sailors' stars / no longer shine. Peace! Pray the Thracians, fierce warriors. / Peace! cry the Medes of the ornate quivers. / All long for peace, O Grosphus, which cannot be bought / by purple gems or gold . . He lives happily upon a little / whose paternal salt-cellar gleams / on a modest table, nor do anxieties / or sordid greed / rob him of soft and soothing slumbers" (trans. by S. Alexander, Princeton 1999); cf. Hor. Carm. 1.1.11-18: Gaudentem patrios findere sarculo / agros Attalicis condicionibus / numquam demoveas, ut trabe Cypria / Myrtoum pavidus nauta secet mare. / Luctantem Icariis fluctibus Africum / mercator metuens otium et oppida / laudat rura sui; mox reficit rates / quassas, indocilis pauperiem pati ("this one's happiness comes from cleaving with the hoe / his paternal fields, untempted even by / the riches of Attalus, too timid a sailor / to plow the Myrtoan Sea in a Cyprian bark. / The merchant, fearfully recalling Southwest winds from Africa / and Icarian waves, extols his rural quiet and / his native place, but after a while, bored / with peace and leisure, incapable of enduring / a mediocre income, he refits his battered vessels"; trans. by S. Alexander, Princeton 1999).

10 The topic of the Aegean Sea's remoteness was previously emphasised by Cicero in De imp. Cn. Pomp. 54-55; Ep. ad Att. 5.12.1-2.

11 See West 1998, 115-116.

12 Hor. Ep. 1.11.1-4, 15-21: "What did you think of Chios, Bullatius, or of famous Lesbos, how did / elegant Samos strike you, or Sardis, royal seat of Croesus, or Smyrna / and Colophon, are they superior or inferior to their reputation? Do / they all pale in significance compared to Mars' Field and the river / Tiber? ... Again, if a stiff south wind / should have tossed you on the deep, that's no reason for selling your / ship on the other side of the Aegean Sea. For a man secure in health / and position Rhodes and Mytilene in their beauty do just as much as / a travelling cloak in summer, a training vest when snowy winds blow, / the Tiber in winter, a stove in the month of August. While you may, / and while Fortune keeps a kind look on her face, at Rome you may / politely reject Samos and Chios and Rhodes in their remoteness" (trans. by J. Davie, New York 2011).

13 Cf. Dilke 1982, 110-112 and esp. Mayer 1994, 190. 
cumbed to the charm of their native Italian land. Commenting upon Roman indifference or reluctance to travel in the abovementioned poem, Horace echoed parochial convictions of his time. Many a simple Roman, airing his personal prejudices against foreigners, laughed at Plautus' jokes about the Greeks, ${ }^{14}$ and treated political exiles returning from Greece as martyrs (notably, Metellus Numidicus, returning in 99 BC, who used his stay on Rhodes and Smyrna mainly to study, ${ }^{15}$ and Cicero, returning in $\left.57 \mathrm{BC}\right) .{ }^{16}$ Such attitudes contrasted with those taken by the earlier Roman elites, who peregrinated in Greece during the Late Republic to broaden their education, refine their manners and impress other people. Relevantly, the Aegean Sea as a concept appears to have symbolically shifted its location. From the 2 nd century to $30 \mathrm{BC}$, the Aegean straddled the outer boundary of the Roman Empire, a watery expanse riddled with infamous pirate raids, rebellions, marauding navies - a danger-ridden area steeped in history and politics. After the battle of Actium, the Aegean became a sleepy, relatively quiet sea in the middle of the Empire, dangerous mostly because of its storms. As expected, Horace's letter discussed above captured the waning Roman interest in Greece or western Asia Minor (the former Kingdom of Pergamon), with Rome turning its attention to newly annexed Egypt, the land of fabulous wonders, with this fascination expressed through Egypt-inspired motifs in literature and art, especially in mural painting. ${ }^{17}$

The imagery of Aegean Sea once again shifts in one of Albius Tibullus' elegies, dated to around $29 \mathrm{BC}$. The sick lyrical subject complains that his illness prevents him from journeying to the East; he meant to follow his patron, Marcus Valerius Messala Corvinus, who was ordered by Augustus to put the Roman affairs in Cilicia, Syria and Egypt in order. After the opening verse of Ibitis Aegaeas sine me, Messalla, per undas, ${ }^{18}$ Tibullus conveys the loneliness and hopelessness of his protagonist, ${ }^{19}$ contrasting his current despair with the myth of the golden age, very popular in the Augustan period. The element of the sea, emphasising the suggestive hopelessness of the ailing man, brackets the entire scene as a dangerous force of nature identified with "a thousand ways of certain death" (Nunc mare, nunc leti mille repente viae) ${ }^{20}$ a passage into the afterlife - the Elysian Fields and the underworld. The poetic vision ends with an image of the Danaides

14 See e.g. Seaman 1954, 115-116; Anderson 1995, 171-180.

15 Liv. Per. 69; App. Bell. Civ. 1.4.33. However, it is worth noting that the later literary reception of Metellus' exile was largely based on its political context (his refusal to swear obedience to a law of the tribune Saturninus), which Cicero used to compared his exile to the predecessor's sacrifice. See Kelly 2012, $152-153$.

16 Plut. Cic. 33.7.

17 See Vout 2003.

18 Tib. Carm. 1.3.1: "Without me will ye go, Messalla, across the Aegean wave" (trans. by J. P. Postgate, LCL).

19 Unable to join Messalla, the poet finds himself on the island of Corcyra, which he calls Phaeacia (Carm. 1.3. 3: Me tenet ignotis aegrum Phaeacia terris), embedding his narrative within the mythological context of the Odyssey and (with appropriately chosen words: tenet - ibitis, terris ignotis - Mors nigra, Mors atra) draws a parallel between his loneliness, a mortal danger in a foreign land, and his friend's equally dangerous and uncertain journey. See Putnam 1973, 74-75; Murgatroyd 1980, 100, 103 (who unfavourably compares the lyrical subject's loneliness to Odysseus' lot); Maltby 2002, 183, 200 (who links the associations between sea, loneliness and death to Prop. Carm. 3.7 (esp. 29-32). A similar bundle of mythological themesan exile on a Greek island and an emphasis on subjective loneliness - can also be observed in Cat., 64 and Ovid. Ep. Her. 10, apparently reflecting the prevalent Roman fear of exile overseas; see Manioti 2017, 45-68.

20 Tib. Carm. 1.3.50. 
carrying water to bottomless barrels - perhaps another allusion to a sea voyage — and the poet's wish that all "who have profaned my love and who have wished me lingering campaigns" (Illic sit, quicumque meos violavit amores, optavit lentas et mihi militias) would end up in the nightmarish land depicted by him. ${ }^{21}$

Another elegiac poet, Sextus Propertius, mentions the Aegean Sea (salum Aegaeum), ${ }^{22}$ the Adriatic, ${ }^{23}$ the half-mythical Rhipaean Mountains (Rhipaei Montes) somewhere in the farthest north and the palace of Memnon, a legendary Ethiopian ruler - the faraway places where Sextus would not be afraid to go to with his friend Tullus, ${ }^{24}$ but he will not do so because he cannot leave his beloved Cynthia (here, the motif of militiae amoris, contrasted with Tullus' actual military service, appears again). ${ }^{25}$ This work of the Umbrian elegiac poet, published in $25 \mathrm{BC}$, facetiously plays with the convention of propempticon and the topos of the sea - a land as distant as it was unreal to the Roman lover,-playing on geographic stereotypes such as "Athenian sophistication", "ancient Asian splendours", "Ionia's exotic expanse" and Lydia, "where the Pactolus' stream tints Lydian fields [gold - B.K.]". ${ }^{26}$ This vision of the Aegean wonders also appears in the poet's another work, the epicedium of one Paetus, a young man who drowned in the Aegean Sea (or, more specifically, the Carpathium mare $)^{27}$ while sailing to Alexan-

${ }^{21}$ Tib. Carm. 1.3.81-82. Militiae in this context refers to the metaphor of a lover-soldier. "Lingering campaigns" therefore connote Tibullus' long separation from Delia, his elegiac lover, but could also refer to a long sea voyage. Cf. Dognini 2002, 220-221.

22 The term salum referred to an open sea, far away from ports and wharfs. Within the stereotyped presentation of the Aegean Sea as a stormy and dangerous one, present already in the earlier Greek literature (cf. RE s.v. Aijoĩov $\pi \dot{\varepsilon} \lambda \alpha \gamma o \varsigma$ ), this meant to reemphasise the courage (ducere vela) of Paetus setting out to this sea. See Cairns 1974, 150.

23 Catullus (Carm. 4.6) earlier referred to the Adriatic Sea as "threatening" (minax), in accord with the general image of the sea in Roman literature, but many more references to the sea's threatening nature denote the Aegean Sea.

24 For more on the topic of Tullus (probably a nephew of L. Volcatius Tullus, a proconsul in Asia in 30-29 BC), see esp. Cairns 1974, 157-163; cf. Richardson 2006, 162-163, who notes, undoubtedly correctly, that such a choice of seas was dictated by Paetus' actual itinerary. We should note, however, that listing the Adriatic and Aegean Seas together with the mythical Rhipaean Mountains and Memnon's palacerespectively the northmost and southmost sites known to the Romans-renders all of them unreal. In this context, the Aegean Sea becomes the easternmost boundary of the poet's imaginings. Baker 2001: 93-94 seems to make a similar interpretation.

25 Prop. Carm. 1.6.1-6. See Clack 1977, 187-189; Fedeli 1980, 182-183; Dognini 2002, 221-222; Richardson 2006, 163.

26 Prop. Carm. 1.6.13-14, 31-32. Cf. Richardson 2006, 163, who notes that the gold deposits of the Lydian river Pactolus had probably been exhausted by Propertius' times; the poet, as in other cases, refers to literary topoi. Cairns $(1974,154)$ correctly notes that the poet employs both vocabulary and motifs associated with tourism (cognoscere, cernere), which underscores his pain of not being able to sightsee the attractions around the Aegean Sea; cf. Fedeli 1980, 176-177, 183; Baker 2001, 95, 98.

27 Prop. Carm. 3.7.12: nunc tibi pro tumulo Carpathium omne mare est; cf. 7. 56-58: Di maris Aegaei quos sunt penes aequora, venti, et quaecumque meum degravat unda caput, quo rapitis miseros primae lanuginis annos? According to Richardson (2006, 344-345), the poet refers here to three powers: to the Aegean gods sensu stricto (mainly Poseidon), to the winds, and to personified water. Accordingly, to rouse the destructive power of the Aegean Sea would equal rousing the wrath of the gods. The motifs of the stormy Aegean and reckless merchants sailing this sea in search of profit also appear in Claud. Ael. Ep. 18. 
dria in search of work, not unlike Alcyone and Ceyx, the protagonists of Publius Ovidius Naso's Metamorphoses. ${ }^{28}$

For the Augustan poets, the Aegean, an emblematically distant region, was certainly not worth travelling to; and if one had to travel there, he risked a sudden death far from home and loved ones. For Ovid, describing his journey into exile to Tomis in AD 8, the Aegean Sea becomes a cold and violent element, which puts up not only a physical but also a psychological fight against the poet on his way to an equally hostile land:

... quod facerem uersus inter fera murmura ponti, / Cycladas Aegaeas obstipuisse puto ... saepe minax Steropes sidere pontus erat . . . saepe maris pars intus erat; tamen ipse trementi / carmina ducebam qualiacumque manu . . quocumque aspexi, nihil est nisi mortis imago . . . barbara pars laeva est avidaeque adsueta rapinae, / quam cruor et caedes bellaque semper habent, / cumque sit hibernis agitatum fluctibus aequor, / pectora sunt ipso turbidiora mari. ${ }^{29}$

Ovid's description, though vivid, is not original in that it builds on a well-established topos in the Roman literature that depicted the Aegean Sea as stormy, inhospitable and trackless, ${ }^{30}$ with later writers simply copying this motif. The only outlier, Publius Papinius Statius, who wrote in the times of Emperor Domitian, reversed the customary direction of the Aegean journey and encouraged the reader to abandon the Greek islands in order to visit Manilius Vopiscus' villa in Tibur:

Scilicet hic illi meditantur pondera mores; / hic premitur fecunda quies, virtusque serena / fronte gravis sanusque nitor luxuque carentes / deliciae, quas ipse suis digressus Athenis / mallet deserto senior Gargettius horto; / haec per et Aegaeas hiemes Pliadumque nivosum / sidus et Oleniis dignum petiisse sub astris, / si Maleae credenda ratis Siculosque per aestus / sit via: cur oculis sordet vicina voluptas? $?^{31}$

Statius' praise of Vopiscus' villa builds on a paradox: it is not the Romans who should risk their lives and sail towards the Aegean Islands but the inhabitants of the Aegean who should head to Italy to admire what Greece lacks. Unlike Horace's poem quoted earlier, Statius' silva does not strictly pit the Italian world against the Greek one, as the poet's reference to Fauns - native Italian creatures - will appear a little later in the text; therefore, Vopiscus' villa combines the best features of both cultures, which further increases its attractiveness to the Romans. In Statius' vision, the Tiburtine estate outshines even the garden of Epicurus in Athens, a glory of Greece and one of its most popular destinations

28 Ovid. Met. 11.410-748.

29 Ovid. Trist. 1.11.7-8, 14, 17-18, 23, 31-34: “. . . my writing of verses amid the wild roar of the sea brought wonder, I think, to the Aegean Cyclades . . . often the constellation of Sterope made the sea to threaten ... Often part of the sea was within our ship; nevertheless, with shaking hand I continued to spin my verses such as they were . . . Wherever I gaze there is naught but the presentment of death ... Wild is the shore on my left, accustomed to the greed of robbers, ever filled with bloodshed and murder and war, and though the sea is shaken by stormy billows my breast is more turbulent than the sea" (trans. by A. L. Wheeler, LCL).

30 See Luck 1977, 90-91. Cf. Lucr. 2.557: infidi maris insidias virisque dolumque; Val. Max. 1.416: qui maris insidias.

31 Stat. Silv. 1.3.90-98: "Ay, here that serious mind broods on weighty themes; here silence shrouds a fruitful quiet and grave virtue tranquil-browed, sane elegance and comfort that is not luxury, such as the Gargettian sage had himself preferred and left his own Athens and his garden behind him; these were worth seeing despite Aegean storms and the Hyades snowy constellation and the Olenian star, even though the bark must be thrown on Malea's mercy and the way lie through Sicilian surges: why do men look slightingly on pleasure near at hand?" (trans. by J. H. Mozley, LCL). 
for Roman peregrinations. ${ }^{32}$ In this regard, it can be said that the wheel of the Roman literature turned a full circle. The Aegean world, initially known to the Romans only from myths and literature, first became familiar and then turned legendary again; for example, it featured in Daphnis and Chloe, a 2nd century CE romance by one Longos (otherwise unknown to us), set in the idyllic scenery of the island of Lesbos. Even this authorial decision, however, reflects the marginalisation of the Aegean Islands, as Longos is, in fact, the only known ancient novelist who decided to set his story in the Aegean. ${ }^{33}$

The idyllic nature of the land depicted by Longos also alludes to another topos, already established at that time, depicting the Aegean Islands as a peaceful land of plenty; however, the idyllic depiction of the region had its darker side, explored as early as in Horace's works. The opulence of the Aegean Islands bred moral corruption, effeminacy and pretentiousness, which Roman writers gladly contrasted with the Roman virtue and simplicity. ${ }^{34}$ Another Roman poet referring to the Aegean, Marcus Valerius Martialis (commonly known as Martial), an outstanding epigrammatist writing under Domitian, reworks the motif of the Aegean corruption in a rather intriguing manner. Penning a malicious pamphlet on a woman named Laelia, the epigrammatist accuses his protagonist of brazen and shameless behaviour, unbefitting the dignity of a Roman woman:

Cum tibi non Ephesos nec sit Rhodos aut Mitylene, / sed domus in vico, Laelia, patricio, / deque

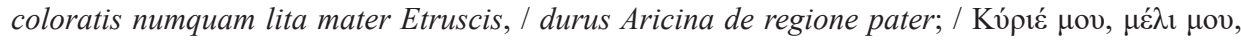

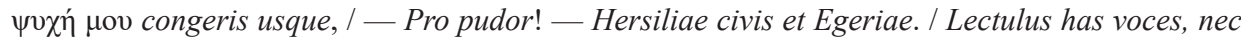
lectulus audiat omnis, / Sed quem lascivo stravit amica viro. / Scire cupis quo casta modo matrona loquaris? / Numquid, cum crisas, blandior esse potes? / Tu licet ediscas totam referasque Corinthon, / Non tamen omnino, Laelia, Lais eris. ${ }^{35}$

The criticism of the protagonist arises from several observable antagonisms. The poet paints Ephesus, Rhodes and Mytilene (juxtaposed with the Patrician Row) as symbols of refined, ostentatious luxury of the Aegean world, where the standard of life exceeded even that of Rome. He contrasts them with the rustic, conservative world of the inhabi-

32 However, Hardie $(1983,178)$ notes that Epicurus' difficult journey across the Aegean Sea to Vopicus' villa only adds to its value, because, in the spirit of Epicureanism, the suffering experienced during the journey would have eventually been compensated by much greater happiness. See also Newlands 2002 , 131-132, 136-138: the author correctly observes that Statius, in his typical fashion, paradoxically juxtaposes Epicurus' philosophy with the Roman predilection for luxury; however, Statius' description of Vopiscus'villa, modelled after the prototypical locus amoenus, is an excellent example of the Epicurean vision of pleasure. For more on connections between the Epicurean philosophy and interior decoration motifs in Roman villas, cf. Myers 2000, 110 and note 29.

33 Longus, 1 Praef.

34 Relevantly to motifs associated with the Aegean, the poet Gaius Valerius Catullus called his lover Lesbia and described her, in accordance with the aesthetics of neoteric poetry, as a beautiful but also very independent woman. The beauty of women from Lesbos was almost proverbial in the antiquity. See Alfonsi 1950, 59-66.

35 Mart. Epig. 10.68: "Although your home is not Ephesus or Rhodes or Mytilene but in Patrician Row, Laelia, and although your mother, who used no make-up, was a daughter of the sunburnt Etruscans and your father came from the district of Aricia, you are always piling on the Greek - 'my lord, my honey, my soul' shame on you, a countrywoman of Hersilia and Egeria! Let the bed hear such expressions, and not every bed at that, but one made for a gamesome gentleman by his lady-friend. Do you wish to know how you talk, you, respectable married woman? Could a waggle-bottom be more blandishing? You may learn all Corinth by heart and reproduce it, but, Laelia, you will not be altogether Lais” (trans. By D. R. Shackleton Bailey, LCL). 
tants of Italy, represented by pastoral Etruria and Aricia, commonly associated with the religious centres of the Latins, and with a local archaic sanctuary of Diana Aricina. Unsurprisingly, Martial employs the adjective durus (tough, hard) to describe Laelia's father as a model farmer-soldier - the modest and hardworking hero of Roman historiography and agronomic literature. The contrast is made starker by Laelia's intertextual speech, quoted by the poet in Greek and thus depicted as empty prattle inappropriate for a patrician's daughter and matron. Martial's punchline scathingly declares that no amount of thoughtless imitation will make Laelia a famous Corinthian courtesan: she will remain an object of ridicule, either due to her glaring violation of decorum, tarnishing her social image and position, or due to being the wrong age for a courtesan. ${ }^{36}$ Whichever interpretation we follow, even if we wanted to include Martial's epigram among works devoted to the topic of improper courting, the poet's dominant compositional motif was the moral antagonism between Rome and the Aegean world - respectively, lands of simple virtue and affluent vice.

A somewhat similar image of the debauched life in the Aegean surfaces in Gaius Petronius' Satyricon: written during Nero's reign, the work depicts a rich freedman Trimalchio, a pompous parvenu with no taste, education or manners, who says about himself that he "led a Chian life from a boy" (a puero vitam Chiam gessi). ${ }^{37}$ To understand what a "Chian life" was supposed to mean (the phrase vitam Chiam gerere being a hapax legomenon found only in this work of Petronius), one should first consider ancient literary depictions of the Chians. ${ }^{38}$

Concerning matters of Chios and its inhabitants, Athenaeus of Naucratis quotes the following authorities: a poet Timocles, according to whom the inhabitants of Chios invented the best kitchen recipes ${ }^{39}$ Critias, according to whom the Chians (alongside the Milesians) are renowned as most skilled bedmakers ${ }^{40}$ Hermippos, who appreciates Chian kylixes ${ }^{41}$ and states that Chian figs enjoy a great popularity in Rome. ${ }^{42}$ Nevertheless, Chios' most famous product was wine. Already favoured by Strabo, Chian wine in Athenaeus' eyes outranks all other beverages, especially the Lesbian wine, in amount and intensity of praise given to it by its appreciators. Other authors also commended Chios as the best of vintages. Pliny the Elder values the excellence of Chian wine on par with wine from Thasos; Galen equally praises the Chian and Lesbian wines, whereas

36 Cf. Watson - Watson 2003, 226-226; Francis 2010, 402.

37 Petr. Sat. 63.

38 Commentators on Petronius (see e.g. De Guerle 1862, 308-309; and esp. Smith 1975, 175 and Schmeling 2011, 260-261) unanimously admit that the ancient Chians were regarded as effeminate, overly dependent on luxury, and even lascivious, an opinion expressed in Paroem. Gr. I 230, where the proverbial Chian (but also Ionian!) laughter is regarded as one of the attributes of the cinaedi; nevertheless, the said commentators did not research this matter in depth. See also Adams (1982, 202), who in his dictionary of Latin sexual vocabulary notes that the Greek literature records some toponymic sexual terms, such as

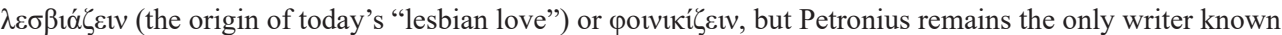
to us who coins such a term (in this case a metonymy for a passive homosexual intercourse) from the name of the island of Chios.

39 Athen. 1.25f; fr. 39 K.-A.

40 Athen. 1.8d; fr. 106 Snell-Maehler.

41 Athen. 11.480e; fr. 55 K.-A.

42 Athen. 3.75f; cf. also Varro, De re rust. 1.4.6; Colum., 10.414 and Calp. Sic., 2.81 and Mart. 7.25.8; 13.23, who - praising Chian figs - simply refers to them as Chiae. 
Claudius Elian equally appreciates the Chian, Lesbian and Thasian vintages but at the same time condemns all of them as conspicuous markers of the Greeks' overly sumptuous lifestyles. ${ }^{43}$

A fondness for wines from Chios, as we will see later, at some point in history ${ }^{44}$ became stereotyped as a behaviour that, depending on a point of view, characterised either those independently wealthy, overly fond of luxury or even those spoilt beyond measure into lewdness and debauchery. Since no similar association existed for appreciators of the Lesbian or Thasian vintages, the ambiguous reputation of Chian wine must have come from the widely held views about the inhabitants of Chios. Some evidence corroborating this conjecture appears in Hegesandros' (2nd c. BC), who records an anecdote about a descendant of Demetrius of Phalerum; accused of living a lavish, rowdy life, he managed to defend himself by accusing the judges of hypocrisy and stressing that his

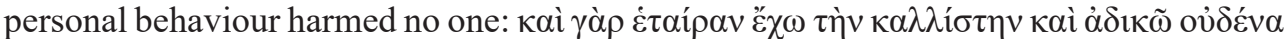

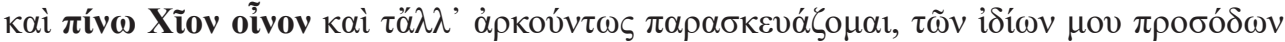

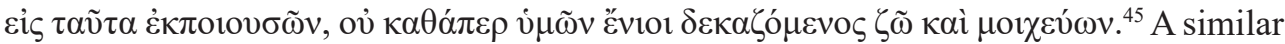
message surfaces in a fragment of Aristophanes' oldest play, Banqueters, cited by Athenaeus, where Chian wine is mentioned together with dirty songs, Syracusan feasts and Sybaritic revelries. ${ }^{46}$ Additionally, these words most likely refer to the play's protago-

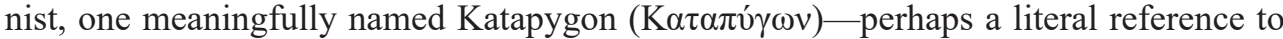
passive homosexual intercourse - such references aligning with other depictions of the Chians and with Trimalchio's behaviour in Petronius' Satyricon, to be discussed later in this text.

We also encounter a reference to the consumption of Chian wine as a marker of a lav-

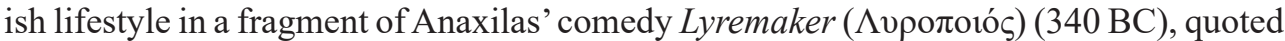

43 Strabo 16.1-2; Athen. 1.28d-29c, 32f; 11.473a; Pliny, NH 14.73; Gal., De meth. med. 12.4 [10.830]; Claud. Ael. Var. Hist. 12.31. References to wines from Chios first appear in Roman literature already in Plautus (Poen. 699-700; Curc. 78). For more on the topic of Greek wines imported to Rome, especially Chian wine and other goods associated with this island, see Dalby 2000, 133-138, 150-151; and esp. Komar 2014a; Komar 2014b.

44 The lack of such references in classical Greek prose, e.g. Herodotus, is puzzling. Probably the oldest surviving work that associates Chian wine with luxury is Aristophanes' play Banqueters $(\Delta \alpha \imath \tau \alpha \lambda \tilde{\eta} \varsigma)$ (see below), of which only short fragments have survived. It is worth noting, however, that, according to Plutarch (De tranq. animi $10=$ Mor. $470 \mathrm{f}$ ), a measure of Chian wine in the times of Socrates was sold for a silver mina, i.e. a sum twenty-five times higher than the local vintage. See Komar 2014a, 236.

45 See Athen. 4.167e; fr. 8, FHG IV, p. 415: "I've got an extremely beautiful lover, I do no one any wrong, and I drink Chian wine and arrange everything else in the way that suits me; and my personal income makes this possible, and I don't live on bribes and illicit sexual affairs, as some of you do" (trans. by S. D. Olson, LCL). Cf. Plut., Dem. 19. 4 on the topic of Demetrius Poliorcetes: "And we are told that once, after Lamia was known of all men to be in complete control of Demetrius, he came home from abroad and greeted his father with a kiss, whereupon Antigonus said with a laugh, 'One would think, my son, that thou wert kissing Lamia'. Again, on another occasion, when Demetrius had been at his revels for several days, and excused his absence by saying that he was troubled with a flux, 'So I learned', said Antigonus, 'but was it Thasian or Chian wine that flowed?"' (trans. by B. Perrin, LCL).

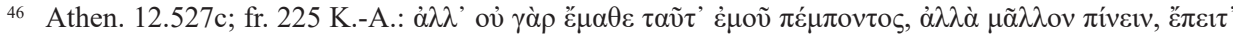

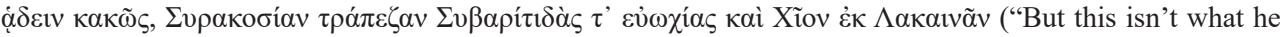
learned when I sent him to school! Instead, [he learned] how to drink, and also how to sing out of key, and what a Syracusan table is, and Sybaritic feasts, and Chian [wine] from Spartan cups"; trans. by S. D. Olson, LCL). These words are probably spoken by Katapygon. See Henderson 1991, 210. 


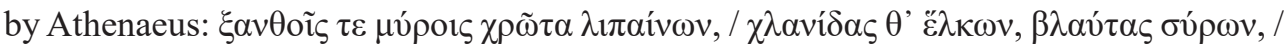

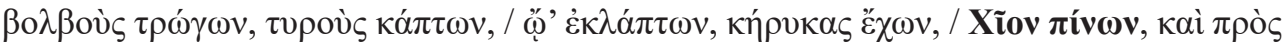

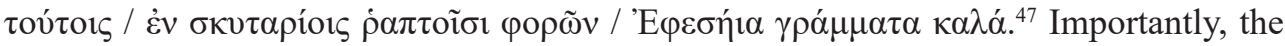
protagonist of Athenaeus' work quotes these verses as, in his opinion, an apt comment on the behaviour of Democritus' pupil, Anaxarchus, who reportedly strayed so far from his master's teachings that he was served Chian wine by a naked girl, and his cook, preparing his pastry, wore gloves and a mask. In this manner, the encyclopaedist additionally strengthened the existing association between Chian wine, extravagance and debauchery, although it is striking that Athenaeus makes no remarks about the customs of the Chians in Book XII of his work, devoted entirely to this topic. However, such a mention does appear in Book XIII. During the protagonists' discussion about beauty, Myrtilus states (a hearsay not confirmed by any other ancient source) that young Chian girls often wrestle with men (allegedly in the nude), a remark met with an outcry of outraged disbelief from Cynulcus. ${ }^{48}$ In turn, Plutarch of Chaeronea associates being fond of Chian wine with being fond of charms of Lais, an elite escort girl, ${ }^{49}$ and lists the Chians alongside the Bithynians and the Galatians as nations whose representatives are always unhappy with

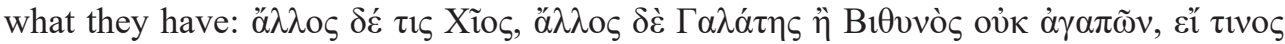
$\mu \varepsilon \rho i ́ \delta o \varsigma$ ก๊̃v

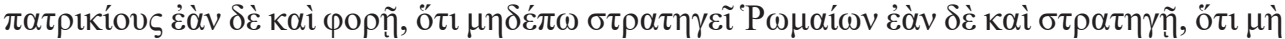

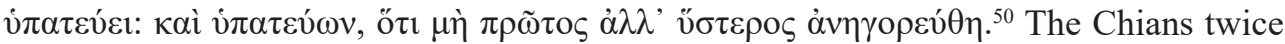

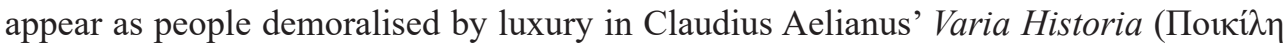

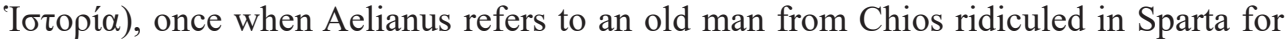
dyeing his grey hair ${ }^{51}$ and for the second time in the form of a Chian who wanted to punish his slave by sending him to the Olympian Games as a spectator, which, he believed, was worse punishment than turning the millstone. ${ }^{52}$ The abovementioned set of literary allusions about the Chians appears to underlie Petronius' phrase, vitam Chiam gessi.

Uttering such a remark, Trimalchio, a former slave, probably meant to sound worldly and dignified, demonstrating that, despite his lowly background, he had always led a prosperous and comfortable life. However, the intertextual tradition on Chian vices and the context of this utterance highlight its satirical undertone. Our protagonist used to have long hair (cum adhuc capillatus essem), which, in the time of early Empire, used to be associated with women rather than with men. ${ }^{53}$ His masculinity is further questioned by the rest of his statement; Trimalchio, referring to intimate relations between his

47 Athen. $12.548 \mathrm{c}$; fr. 18 K.-A.: "oiling his skin with golden perfumes, trailing clothes, dragging slippers, eating hyacinth bulbs, gobbling cheeses, gulping down eggs, having whelks, drinking Chian wine, and on top of all that, wearing lovely Ephesian letters in scraps of stitched leather" (trans. by S. D. Olson, LCL).

48 Athen. 13.566e.

49 Plut. Non posse $17=$ Mor. $1099 \mathrm{a}-\mathrm{b}$.

50 Plut. De tranq. animi $10=$ Mor. $470 \mathrm{c}-\mathrm{d}$ : "Yet there are others, Chians, Galatians, or Bithynians, who are not content with whatever portion of either repute or power among their own fellow-countrymen has fallen to their lot, but weep because they do not wear the patrician shoe; yet if they do wear it, they weep because they are not yet Roman praetors; if they are praetors, because they are not consuls; and if consuls, because they were proclaimed, not first, but later" (trans. by W. C. Helmbold, LCL).

${ }_{51}$ Claud. Ael. Var. Hist. 7.20; cf. Stob. 3.12.19.

52 Claud. Ael. Var. Hist. 14.18.

53 Cf. e.g. Athen. $12.527 \mathrm{c}-528 \mathrm{~d}$, where a man's long hair is one of the symptoms of his effeminacy. 
master and his young slave, forgets himself and goes overboard in his ambiguous praise of the young lover: ipsimi nostri delicatus decessit, mehercules margaritum, sacritus et omnium numerum. ${ }^{54}$ In result, Trimalchio puts himself on par with his former owner, with whom he seems to have shared pleasure, i.e. what in the opinion of the ancient distinguished a truly free man from a slave, or broadly defined lower classes, who could not afford such indulgence. The subsequent portion of the text further satirises and highlights the contrast between true nobility of Roman character and Trimalchio, a vulgar nouveau riche freedman aspiring to being perceived as sophisticated and cultured. Before a meal, our protagonist tells a story (using choice words), as awful and distasteful as it is absurd, about witches kidnapping the body of the mentioned boy and planting a straw baby in its place. ${ }^{55}$ When referring to himself as a Chian, Trimalchio might have wanted to draw on different associations than we might presume. In the eyes of a nouveau riche freedman in the times of Nero, a Chian life may have been seen as pleasurable and easy; in the eyes of the intellectual elite of that time, to which Petronius belonged, a Chian life connoted bad taste and pretence, if not moral depravity.

Another negative set of associations connected with the Roman literary reception of the Aegean islands in the Principate concerned islands used as places of exile; it is difficult to avoid the impression that it was the unfavourable image of this region and the stereotypes related to it that significantly contributed to the choice of these islands as a place for isolating people who were unwelcome in the capital city. The phenomenon of using the Aegean islands as desolate banishment sites constitutes perhaps the most glaring example of the Roman control over the Aegean Sea. Accordingly, the reception of Aegean exiles in Roman Principate literature sensu stricto - and in the Roman geographical and cultural imagination sensu largo - appears particularly relevant to this analysis, especially since references to Roman exiles in the Aegean have so far been treated either as historical sources or as an otherwise undistinguished part of the broader exile literature, yet not as a separate literary phenomenon. ${ }^{56}$

The first well-publicised cases of Romans being exiled to the Aegean islands appear to have taken place towards the end of the rule of Emperor Augustus ${ }^{57}$ and during the reign of his successor, Tiberius. Almost all our information on these cases comes from the Annals of Publius Cornelius Tacitus, clearly biased against almost all the rulers who had held power before his contemporary emperor, Trajan. Even in the context of Tiberius' enforced stay on Rhodes between 6 BC and AD 2 (out of eleven Tacitus' references to Rhodes, nine consider Tberius $\left.{ }^{58}\right)$, Tacitus cannot write one good word about the future emperor. According to Tacitus, the enforced stay on the Aegean island left Tiberius very

54 Petr. Sat. 63: "When I was still in long hair [you see, I led a very soft life from my boyhood] the master's pet slave died. He was a pearl, honest to god, a beautiful boy, and one of the best" (trans. by J. P. Sullivan, Penguin Classics 2012). On the sexual implications of the above epithets which supplement the phrase vitam Chiam gessi see esp. Schmeling 2011, 260-261.

55 Cf. Paratore 1933, 221-222.

56 See Braginton 1944; Amiotti 1995; Claassen 1999; Bingham 2003; Santalucia 2004; Gaertner 2007; Baslez 2008; Cohen 2008; Guerin-Beauvois 2008; Rivière 2008; Drogula 2011; Kelly 2012; Rapske 2013.

57 The Roman law included punishment by banishment to the islands fairly late: lex Iulia de adulteriis coercendis, issued against adulterers by Augustus, was passed in 18 BC. See Amiotti 1995, 246.

58 Tac. Ann. 1.4.53; 2.42; 3.48; 4.15, 57; 6.10, 20, 51. Cf. geographical mentions in Ann. 2.55; Hist. 2.2 and historical ones in Ann. 12.58 . 
lonely and distorted his character. ${ }^{59}$ As a result, Rhodes in Tacitus' work, a deserted spot inimical to the Roman virtue, never attracts the writer's interest after the death of Tiberius. The other Aegean islands also interested Tacitus only inasmuch as their connection to repressions inflicted by successive rulers. Tacitus' Aegean islands, places of exile and execution, fit the newly evolving, bleaker image of this region. ${ }^{60}$

Penal associations of the Aegean probably stemmed from the very choice of islands to which Roman exiles were sent, usually small, sparsely populated and lacking in any comforts, such as Gyaros and Seriphos ${ }^{61}$ however, better-connected and luckier convicts were occasionally sent to larger, pleasanter islands. ${ }^{62}$ Stereotypes about individual islands may have impacted the actual situation of the prisoners and emperors' future behaviour, as pertinently illustrated by two exile cases. The first one, Junius Gallio, exiled in $32 \mathrm{AD}$ by Tiberius to Lesbos, returned to Rome after other senators allegedly started to complain that his exile was more of an extended holiday (incusabatur facile tole raturus exilium delecta Lesbo, insula nobili et amoena) ${ }^{63}$ In his case, the wide-known loveliness and charm of Lesbos outweighed the hardships of banishment, viewed as unequivocally negative in the Republican period; after all, Metellus Numidicus, enthusiastically welcomed in Rome after his return, had also been confined to this island. It is therefore not surprising that almost no more records survive of Roman exiles being sent to islands seen as scenic and agreeable. ${ }^{64}$ Another exile, Aulus Avillius Flaccus, the prefect of Egypt in 32-38 AD, had been one of the accusers of the emperor's family members, came into a bitter conflict with the local Jewish community, and, in result, was sentenced to banishment by Caligula in 38 . His exile to the island of Gyaros - "that most miserable

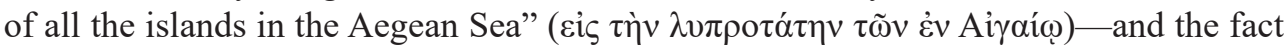
that he "was banished from the whole mainland - that is, the greater and better part of the habitable world - and from every island on which people can prosper" ${ }^{\prime 65}$ feature in a text by Philo of Alexandria, who, not being a Roman, nevertheless referred in his description to the Roman vision of the islands and tried to faithfully render Flaccus' perspective. ${ }^{66}$ Thanks to the intercession of Marcus Aemilius Lepidus, Caligula's friend, Flaccus ultimately did not end up on Gyaros; instead, he was exiled to Andros, a less desolate and yet still thoroughly unpleasant island. Philo comprehensively emphasises Flaccus' social

59 For more on the topic of Tiberius' Rhodian exile, see Weller 1958, passim.

${ }^{60}$ Previous commentators on Tacitus did not comment on this issue. See e.g. Goodyear 1981; WoodmanMartin 1996; Martin 2001.

${ }^{61}$ See e.g. Tac. Ann. 4.21 and 30, where Seriphos is actually called a rock (saxum) bereft of water (egena aquae); 3.66-69: immitem et sine cultu hominum esse (on Gyaros); 4.13 and 30.

62 See Rapske 2013, 328-332.

63 Tac. Ann. 6.3: "he drew censure for being likely to endure exile easily on his chosen Lesbos, a noted and attractive island" (trans. by A. J. Woodman, Indianapolis-Cambridge 2004).

64 The sole exception was the exile of a well-known rhetorician Favorinus of Arelate, banished to the island of Chios on Hadrian's orders, mentioned in a papyrus found in 1931 that records extensive fragments of the convict's self-consolation. The topic of banishment to the Aegean Islands for political reasons remained relevant during the rule of the Antonine dynasty as well. See Braginton 1944, 402; Amato 2000. In this case, the exile to a pleasant island may have resulted from Favorinus' high social position, although it also cannot be ruled out that some role may have been played by the negative stereotypes about the Chian life discussed above, since this famous orator was a hermaphrodite.

65 Phil. Flacc. 151. Cf. Van der Horst 2003, 223-224.

${ }^{66}$ Baslez 2008: 181. 
(losing his prestige, position and freedom) and psychological degradation: the exile suffers due to his banishment from the mainland and the necessity to move to the Aegean Islands (with the early distinction between rich and poor islands still bearing on Flaccus' fate). Describing Flaccus' dispiriting journey, Philo deliberately enumerates the smallest islands, only to become lost among their plethora: ${ }^{67}$

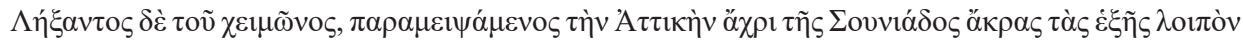

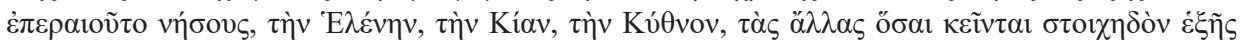

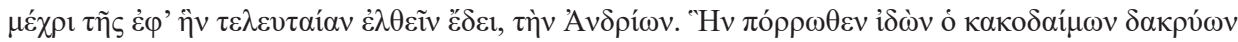

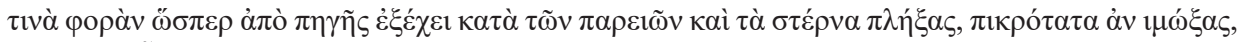

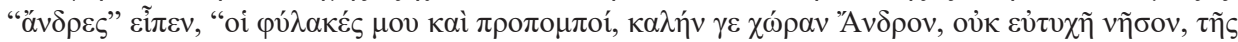

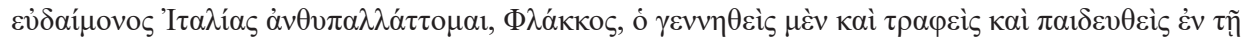

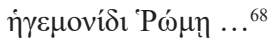

Philo recycles and twice alludes to the already familiar motif of the stormy, distant Aegean, emphasising the contrast between Italy and islands of Greece; another familiar topos, the exile's despair, closely follows the precedent in Ovid's Tristia, so we could easily dismiss Philo's description as unoriginal. However, the Jewish writer's artistry in reusing old topoi shines in the psychological depth of his depiction. The place of exile-

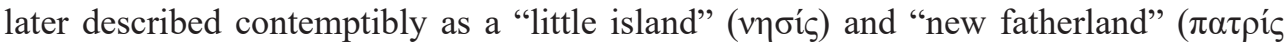

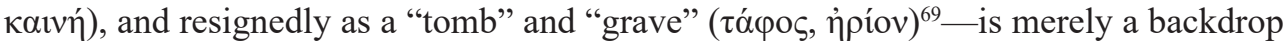
for the protagonist's internal drama. Flaccus, left on the island by his guards, falls into apathy and fear; subsequently, paranoia, loneliness and guilt bring him to the verge of madness; his suffering ends in death, since Caligula, not unlike Tiberius in the case of Junius Gallio, believed that those he exiled enjoyed themselves too much on supposedly paradisiacal islands of the Aegean ${ }^{70}$ and ordered the execution of the best-known ones, like Flaccus. ${ }^{71}$

Infamous banishments of the Julian-Claudian and Flavian emperors undoubtedly somewhat tainted the rosy vision of the wealthy Aegean Islands, although recalls and purges of exiles in the Aegean, who were thought to have been enjoying themselves, imply that the Romans still associated the Aegean with pleasant, luxurious life on picturesque islands and in opulent cities on Lesbos, Rhodes and the coast of Asia Minor, even if actual references to the alleged pleasures of the Aegean appeared less frequently in the later Roman literature. If this is correct, then the public Roman image of the Aegean Sea seems to have bifurcated at some point along the land/sea divide: either an almost mythi-

67 Cf. Box 1939: XLVIII note 5; Van der Horst 2003, 227.

68 Phil. Flacc. 156-158: "When the storm had ceased, he coasted along Attica as far as Cape Sounion and then continued along the series of islands there, Helena, Kia, Kythnos, and all the others that lie in a row one after the other, until at last he came to his destination, the island of the Andrians. When he saw it from afar, the wretch cried so uncontrollably that his tears seemed to come from a fountain. Beating his breast and lamenting bitterly, he said: 'My guards and escorts, look what a fine piece of land this Andros is, an unhappy island that I exchange for happy Italy! I, Flaccus, was born and brought up and educated in imperial Rome'" (trans. by W. Van der Horst, Leiden-Boston 2003).

69 Phil. Flacc. 159.

70 Phil. Flacc. 183-184.

71 Cf. Phil. Leg. 341-342; Suet. Gai. 28; Cassius Dio 59.18.3. 
cal land of prosperous, large islands and metropolises, or a dangerous, distant, billowy sea surrounding desolate rocks of exile. ${ }^{72}$

The latter, negative Aegean topos features in select satires by Decimus Iunius Iuvenalis (or Juvenal, 2 nd half of the 1 st c. to the 1 st half of the 2 nd c. CE), reflecting the popularity of this topic at the turn of the 1 st and 2 nd centuries, also in programmatic satire. In Satire I, the island of Gyaros, deliberately mentioned in the plural form (brevibus Gyaris), symbolises crime, allegedly rampant in Rome in the author's day:

Aude aliquid brevibus Gyaris et carcere dignum, / si vis esse aliquid. probitas laudatur et alget; / criminibus debent hortos, praetoria, mensas, / argentum vetus et stantem extrapocula caprum. ${ }^{73}$

The author's recognizably negative view on Gyaros and his ironic diction become obvious only when considered in context of the entire surrounding passage, dealing with various types of crimes. In Juvenal's vision, committing a crime punishable by banishment becomes a reason for pride. Similarly, the poet juxtaposes righteous men, unctuously yet dishonestly praised by scoundrels living in the lap of luxury, with exiles who attract public attention and lead easy lives in their places of internment. In Juvenal's world, nobleness mixes with crime and the truth with lies.

The second Aegean Island mentioned by Juvenal is Seriphos, named in Satire VI (the so-called "misogynous" one):

Inde fides artis, sonuit si dextera ferro / laevaque, si longe castrorum in carcere mansit. / Nemo mathematicus genium indemnatus habebit, / sed qui paene perit, cui vix in Cyclada mitti / contigit et parva tandem caruisse Seripho. ${ }^{74}$

The consequences of imperial disfavour - the banishment to a rocky island, long interrogations, fear of capital punishment - are ironically recast by the poet as the vicissitudes of fortune that test and in turn testify to the astrologer's high qualifications. Although successive emperors have persecuted members of this profession, they undoubtedly meted out aforementioned punishments only on the most notable astrologers, whom, for one reason or another, they did not want immediately executed. ${ }^{75}$

The association of the small islands on the Aegean Sea with penal colonies also appears in Juvenal's Satire XIII, which focuses on the problems one Calvinus has with a dishonest debtor. Towards the end of the poem, Juvenal-presumably, in deliberate contradiction to the Stoic view on punishment as moral atonement for villainy, the view

72 The Aegean Islands used for this purpose by the Romans, including Gyaros, were reused as prisons in the modern era: for example, during the government of Ioannis Metaxas in 1936-1941, between 1948 and 1953, as well as during the Regime of the Colonels in 1967-1974. It could therefore be said that the ancient Roman practice surprisingly resurfaced after a very long interval. See Constantakopoulou 2007: 133-134.

73 Iuv. Sat. 1.73-76: "If you want to be anybody nowadays, you must dare some crime that merits narrow Gyara or a gaol; honesty is praised and starves. It is to their crimes that men owe their pleasure-grounds and high commands, their fine tables and old silver goblets with goats standing out in relief' (trans. by G. G. Ramsay, LCL).

74 Iuv. Sat. 6.560-564: "For nowadays no astrologer has credit unless he has been imprisoned in some distant camp, with chains clanking on either arm; none believe in his powers unless he has been condemned and all but put to death, having just contrived to get deported to a Cyclad, or to escape at last from the diminutive Seriphos" (trans. by G. G. Ramsay, LCL).

75 See Courtney 2013, 81, 290-292; Watson - Watson 2014, 252-253. For more on the topic of Seriphos, see esp. Drogula 2011, 241-243, 251, 256-257. 
he expressed earlier - consoles his friend by saying that the guilty man will undoubtedly commit another crime and justice will be served:

Quisnam hominum est quem tu contentum videris uno / flagitio? dabit in laqueum vestigia noster / perfidus et nigri patietur carceris uncum / aut maris Aegaei rupem scopulosque frequentes / exulibus magnis. poena gaudebis amara / nominis invisi tandemque fatebere laetus / nec surdum nec Teresian quemquam esse deorum. ${ }^{76}$

Calling the Aegean exiles "great" (magni) ["noble" in the cited translation], Juvenal may either refer to the harshness of sentences and egregiousness of committed crimes or ironically allude to exile islands themselves, described with words such as "rocks" (rupes) and "crags" (scopuli). Certainly, not all exiles to the Aegean were notorious or were being punished on trumped-up charges. However, the elites still believed in such stereotypes; Pliny the Younger, Juvenal's contemporary, praised emperor Trajan by stating that previous emperors unjustly exiled innocent and highly placed people to these rocks (cautes) of solitude, while Trajan chose to banish only the worst and most deserving scoundrels there. ${ }^{77}$

Juvenal also referred to the topos of the Aegean islands as a grave; known to us already from Philo's work, this topos clashes with the overriding ambition and hubris of a man who cannot be happy with what he already has. In this role, the satirist used the emblematic figure of Alexander the Great:

Unus Pellaeo iuveni non sufficit orbis, / aestuat infelix angusto limite mundi / ut Gyarae clausus scopulis parvaque Seripho; / cum tamen a figulis munitam intraverit urbem ${ }^{78}$ / sarcophago contentus erit. ${ }^{79}$

The fragment of the satire quoted above stands for the last analysed piece of imperial literary tradition on the Aegean islands, with the smallest of them (that is, Seriphos and Gyaros) ridiculed as extremely insignificant points in the sea, lacking in comforts and points of interest, which returns us to the folk etymology that cast the Aegean islands as goats. Whenever these islands are mentioned, e.g. in the quoted satire, they are

76 Iuv. Sat. 13.243-249: "What man have you ever seen that was satisfied with one act of villainy? Our scoundrel will yet put his feet into the snare; he will have to endure the dark prison-house and the staple, or one of those crags in the Aegean sea that are crowded with our noble exiles. You will exult over the stern punishment of a hated name, and at length admit with joy that none of the Gods is deaf or like unto Tiresias" (trans. by G. G. Ramsay, LCL).

77 Pliny, Pan. 35: Quantum diversitas temporum posset, tum maxime cognitum est, cum isdem quibus antea cautibus innocentissimus quisque, tunc nocentissimus affigeretur; quumque insulas omnes, quas modo senatorum, iam delatorum turba compleret, quos quidem non in praesens tantum, sed in aeternum repressisti, in illa poenarum indagine inclusos ("Then indeed we knew how times had changed; the real criminals were nailed to the very rocks which had been the cross of many an innocent man; the islands where senators were exiled were crowded with the informers whose power you had broken for all time, not merely for a day, held fast as they were in the meshes of punishments untold"; trans. by B. Radice, LCL).

78 I.e. Babylon in $323 \mathrm{BC}$. The reference to potters (figuli) defending Babylon is an allusion to its famous brick walls. It also serves to depreciate the city in which the insatiable conqueror ended his life. See Courtney 2013: 414.

79 Iuv. Sat. 10.168-172: "One globe is all too little for the youth of Pella; he chafes uneasily within the narrow limits of the world, as though he were cooped up within the rocks of Gyara or the diminutive Seriphos; but yet when once he shall have entered the city fortified by the potter's art, a sarcophagus will suffice him!" (trans. by G. G. Ramsay, LCL). 
associated with exile, but every such association derivatively recycles opinions already widespread in the classical Greece. ${ }^{80}$ Adapted by the Romans, this old Hellenic motif incongruously merged with the Roman vision of the Aegean Sea, most probably contributing to the Romans choosing the Aegean islands as places of banishment, which in turn reinforced literary topoi that led to this choice in the first place.

Considering two islands mentioned in the passage above, let us start with Gyaros, that was seen negatively even before it became a place of exile. Virgil poetically depicted Gyaros (and the neighbouring island of Mykonos) as merely an anchor for something much more significant for the Romans - that is, the island of Delos. ${ }^{81}$ In turn, Ovid mentioned Gyaros among very few islands which did not participate in the conquests of King Minos, although e.g. the "marblestone" Paros and the "low" (humilis) Mykonos did so. ${ }^{82}$ Quoting Marcus Terentius Varro, Pliny the Elder relayed an anecdote that the inhabitants of Gyaros had once been chased away by mice. ${ }^{83}$ The amusing story must have predated Varro: Stephanus of Byzantium, referring to the mice of Gyaros in his 6th century dictionary, excerpted this information from the paradoxographer Antigonus of Carystus, who lived in the 3rd century BC. Under the entry for Gyaros (which, according to Stephanus, belonged to the archipelago of the Sporades), we can read that "mice bite through iron there and wild pear trees have poisonous wood". Indeed, Stephanus' Gyaros does not entice travellers with its charm.

Similar opinions were expressed about Seriphos, this time drawn primarily from the Greek literature. ${ }^{84}$ The first Roman author to depict Seriphos negatively was Marcus Tullius Cicero, who recorded an anecdote about Themistocles (probably taken from Plato); one of Themistocles' opponents taunted the famous statesman that he would never have become successful if he had come from Seriphos rather than from Athens. ${ }^{85}$

In another work disparaging Seriphos, Cicero uses the example of this island to disprove Epicurus' extreme brand of empiricism, noting that someone raised on Seriphos would have experienced only the diminutive fauna of this island and would thus never believe in the existence of much larger animals living on the mainland:

80 E.g. Aristoph. Acharn. 542; Plat. Rep. 329e. Cratinus wrote an entire comedy about the inhabitants of Seriphos. See Constantakopoulou 2007, 103-104.

81 Verg. Aen. 3.75-77. For the significance of Delos in the Roman times (beginning in the Republican period), see Rauch 1993; Zarmakoupi 2015.

82 Ovid. Met. 7.461-471.

83 Pliny, $N H$ 8.43.

${ }_{84}$ See e.g. Strabo 10.5.8, where we can read the opinion that Medusa's gaze cursed Seriphos to be rocky and barren, since it was this island's king that sent Perseus to bring the monster's head. Seriphos allegedly was a place so forgotten by the gods that even frogs did not croak in a natural way there. See Pseudo Arist., De mir. auscult. 70; Ael. Hist. Anim. 3.37; Suda, s. v. Batrachos ek Seriphou. For peculiar features of Seriphos, also see Freely 2006, 42-48.

85 Cic., De senect. 3,8 after Plat. Rep. 329e. Interestingly, according to an older version of the anecdote recorded by Herodotus (8.125), the island in question was Belbina; it appears that later authors replaced Belbina, a literally unknown island of no reputation, with Seriphos, an island ironically known mainly for being insignificant. The anecdote in the Platonian version was also mentioned by Plut. Them 18.5. Cf. Constantakopoulou 2007, 105. 
Quae sunt tantae animi angustiae, ut, si Seriphi natus esses nec umquam egressus ex insula, in qua lepusculos vulpeculasque saepe vidisses, non crederes leones et pantheras esse, cum tibi, quales essent, dicerentur, si vero de elephanto quis diceret, etiam rideri te putares. ${ }^{86}$

Seriphos, or, more broadly speaking, the islands seen as exile spots in the 1st and 2nd centuries $\mathrm{CE}^{87}$ had been treated as stereotyped spaces of isolation, oppression and restrictions; how restrictive the island conditions actually were, however, depended mainly on the personal attitude of those exiled, as Lucius Anneus Seneca the Younger tried to persuade his mother after he was relegated to Corsica (staying there until $49 \mathrm{CE}$ ). In Seneca the Younger's comforting reflections, some world-weary travellers go of their own accord to "desert places" (deserta loca) and "the wildest islands" (asperrimae insulae) (such as Skiathos, Seriphos, Gyaros or Kossura) in search of loneliness and quiet (Flavius Philostratus later mentioned similar travellers visiting the reclusive philosopher Musonius Rufus on Gyaros). A wise man, according to Seneca, finds home at any place, no matter how secluded it is. ${ }^{88}$ In contrast to these "desert places," Seneca mentions Rome, the "capital of the world" (civitas communis), as paradoxically much less attractive to these "eternal wanderers" searching for inner peace ${ }^{89}$ Of course, there are reasons to doubt Seneca's veracity of the strength of his conviction. This teacher and adviser of Nero eventually returned to worldly Rome, renouncing quiet comforts of the islander life as soon as he could; still, there is no doubt that Seneca the Younger's creative reuse of the motif of the Aegean Islands as sea prisons remains one of its most original reiterations in the Roman literature.

This article mentioned many Aegean islands, some more famous than others; the question remains which of them were commonly known and which of them were familiar only to the Roman elite, the intended literate audience of works discussed above. Due to the lack of surviving sources, this question cannot be answered in a satisfactory manner. Even Roman compendia of popular knowledge, such as Pliny the Elder's Natural History, did not devote particular attention to this topic; geographic catalogues contained within, indiscriminately copied by later authors, reflected the general state of geographical knowledge at that time but can hardly be regarded as reliable. What we are left with are literary marginalia, texts surviving until our day by a lucky accident, since

86 Cic. De nat. deor. 1.31.88: "How can such narrowness of mind be possible? It follows that, if you had been born in Seriphus and had never left the island, where you had been used to seeing nothing larger than hares and foxes, when lions and panthers were described to you, you would refuse to believe in their existence; and if somebody told you about an elephant, you would actually think that he was making fun of you!" (trans. by H. Rackham, LCL).

${ }^{87}$ Cf. also Plut. De Exilio 7, who tells an anecdote about a certain witty poet who, while staying on Seriphos, asked his host why local prisoners had been banished there; when he found out that they bribed others, he was surprised why they would not engage in bribery again and be driven off this desolate island as well, perhaps to a more pleasant place. Subsequently, the writer also mentions Gyaros and Kinaros as other places of banishment.

88 Cf. e.g. Epict. Diatr. 1.1.18-24; 4.24; 11.33; 18.17; 19.7-9; 29.5-6; 30.2; 2.6.18-19; 13.22; 19.18; 3.8.2; 24.29; 4.1 .60 and 132-137; Plut. De Exil. 8.1. In this case, the observation of C. G. Starr $(1949,25)$ seems to be right on the mark; in his opinion, disparaging references to the islands of Gyaros and Seriphos resemble contemporary connotations attached to places where Nazi camps were once located, such as Dachau or Buchenwald.

89 Sen. Min. Ad Helv. 6.4-6. Cf. Guerin-Beauvois 2008, 194. 
their authors never meant to have them preserved for posterity. One of such texts was the Liber memorialis, a lesson plan or textbook one Lucius Ampelius, an anonymous tutor who lived in the 2 nd century AD, wrote for his student Macrinus. Apart from sections about mythology, history and political systems, the Liber contains a geography-oriented part that indexes "main Greek islands", probably for rote memorisation. At its beginning, Ampelius mentions the "best-known ones" (clarissimae): in the Aegean, these encompass Crete, Euboea, Lesbos and Rhodes. The former two islands, Crete and Euboea, were known to the Romans only in their mythological and historic context; although large, they were neither rich, cultured nor attractive to a common tourist. Otherwise undistinguished, they remained unattractive to Roman writers. "Apart from these," we then read, "there are twelve Cyclades in the Aegean Sea: Delos, Gyaros, Mykonos, Andros, Paros, Tenos, [Ios], Kythnos, [Sifnos], ${ }^{90}$ Melos, Naxos, Donusa; also the countless Sporades, the most famous of which are Egina, Salamina, Kos, Chios, Lemnos and Samothrace". ${ }^{91}$ Ampelius has clearly preselected his material, diving the islands into clarissimae, celeberrimae and innumerabiles, the latter adjective reflecting the authorial conviction that unnamed islands remain insignificant - not worth thinking about. ${ }^{92}$ The manual suggests that a student who "wants to know everything"93 should only recognise the islands mentioned above (and perhaps know something about them as well, as indicated in the following part of the text), although Ampelius is not entirely consistent and subsequently adds a note on the island of Samos (a significant tourist attraction). ${ }^{94}$ Ampelius' list evidently by and large overlaps the catalogue of islands discussed in this article. On the list we find Rhodes and Lesbos, commonly associated with luxury, treated separately by Ampelius not so much due to their size as to their fame. The presence of the tiny Cyclades (such as Gyaros, Kythnos and Donusa) and absence of larger and more famous islands would be surprising, if it were not for popular stereotypes depicting them as places of isolation and "rocks" (scopuli), significant in their insignificance. As a comparandum, Hyginus' catalogue of the Aegean islands, compiled in the Augustan period, short and devoid of any commentary, also enumerated Seriphos, Gyaros and Rineia, ${ }^{95}$ the last one only $14 \mathrm{~km}^{2}$ in area. Other Aegean islands listed by Hyginus featured in the Roman literature thanks to their specific products or cultural phenomena: Paros with its highly-valued marble, Chios with its wine, and Samothrace (also listed by Ampelius) with its Samothracian Mysteries, popular in Rome, and with the cult of the Cabeiri. ${ }^{96}$ Once again, we return to the substratum of the Greek myth which enveloped the Aegean and ushered these islands into the Roman literary imaginarium.

The image of the Aegean islands in the Roman literature was somewhat incongruously compressed into contradictory visions: islands of plenty, desolate prisons, always

90 Addition by Arnaud-Lindet 1993.

91 Amp. Lib. mem. 6.12-14.

92 Oliveira $(2017,29-32,42)$ also appraises the descriptions of islands in the work of Pliny the Elder, considering how Pliny's choice of adjectives reflects his authorial choices in regard to material selection.

93 Amp. Praef.

94 Amp. 8.13.

95 Hyg. Fab. 276. The author mentions nine islands in the archipelago of the Cyclades: Andros, Mykonos, Delos, Tenos, Naxos, Seriphos, Gyaros, Paros and Rineia. Apart from the Cyclades, he also enumerates the following "largest islands" of the Aegean: Rhodes, Euboea, Crete, Tenedos and Sikyon (sic!).

96 Amp. 2.3. 
located far from Italy, surrounded by the terrifying marine element. The positive associations stemmed from previous cultural contacts between the Aegean and Rome: the Romans admired the supposedly more developed Greek civilisation (their awe sometimes tinged by ostensible disparagement), whereas their elites enjoyed their Aegean tours and reminisced about past glories of Rhodes and Athens. ${ }^{97}$ The negative associations came from the islands' desolation and insignificance; the imperial authors, associating the Aegean islets with exile spots, borrowed such motifs from classical and Hellenistic Greek predecessors. This bivalent system of positive and negative references arose at the intersection of Roman ideas on culture and nature: past cultural glories of Greece clashed with the unpredictable and corrupting sea, a uniformly negative element in the Roman literature. Out of these convergences were born other visions of the Aegean, occasionally captured in surviving works. The Aegean Sea, ever-present in the rich Greek mythical imaginarium, inspired writers interested in myth and folklore; other writers associated its islands with excellent crops and products, renowned and valued across the Empire. The Aegean islands in the Roman times undoubtedly lived in the shadow of continental Greece, but they must have had a powerful sway over the Roman imagination; people in faraway Latium, living their mainland lives, fantasised about opulent and exotic islands across the stormy sea, places of opportunity and danger.

BIBLIOGRAPHY

Adams, J. N. (1982), The Latin Sexual Vocabulary, London.

Alfonsi, L. (1950), Lesbia, AJPh 71/1: 59-66.

Amato, E. (2000), Favorino, Sul „proprio” esilio, ZPE 133: 43-50.

Amiotti, G. (1995), Primi casi di relegazione e di deportazione insolare nel mondo romano, in: M. Sordi (ed.), Coercizione e mobilità umana nel mondo antico, Milano: 245-258.

Anderson, W. S. (1995), The Roman Transformation of Greek Domestic Comedy, CW 88/3: 171-180.

Arnaud-Lindet, M.-P. (1993), Lucius Ampelius, Aide-mémoire, Paris.

Baker, R. J. (ed.) (2001), Propertius I, Warminster.

Baslez, M.-F. (2008), La relégation dans les îles: un espace repensé par les intellectuels exilés, in:

P. Blaudeau (ed.), Exil et relégation. Les tribulations du sage et du saint durant l'Antiquité romaine et chrétienne (Ir-VIe s. ap. J.-C.). Actes du colloque organisé par le Centre Jean-Charles Picard, Université de Paris XII-Val de Marne (17-18 juin 2005), Paris: 179-190.

Bingham, S. (2003), Life on an Island: A Brief Study of Places of Exile in the First Century AD, in:

C. Deroux (ed.), Studies in Latin Literature and Roman History XI, Brussels: 376-400.

Borca, F. (2000), Terra mari cincta: Insularità e cultura romana, Rome.

Box, H. (ed.) (1939), Philonis Alexandrini in Flaccum, London.

Braginton, M. V. (1944), Exile under the Roman Emperors, CJ 39/7: 391-407.

Cairns, F. (1974), Some Problems in Propertius 1.6, AJP 95/2: 150-163.

Claassen, J.-M. (1999), Displaced Persons: The Literature of Exile from Cicero to Boethius, MadisonLondon.

97 See e.g. Cic. De imp. Cn. Pomp. 54-55. 
Clack, J. (1977), Non Ego Nunc (Propertius 1.6), a Study in Irony, $C W 71 / 3: 187-190$.

Cohen, S. T. (2008), Augustus, Julia and the Development of Exile "Ad Insulam", CQ 58/1: 206-217.

Constantakopoulou, Ch. (2007), The Dance of the Islands: Insularity, Networks, the Athenian Empire, and the Aegean World, Oxford.

Courtney, E. (2013), A Commentary on the Satires of Juvenal, Berkeley.

Dalby, A. (2000), Empire of Pleasures: Luxury and Indulgence in the Roman World, London-New York.

De Guerle, J. N. M. (ed.) (1862), Oeuvres complètes de Pétrone, Paris.

Dilke, O. A. W. (ed.) (1982), Horace, Epistles: Book I, Letchworth.

Dognini, C. (2002), „Militia amoris” e „militia Caesaris” nell'elegia latina, in: M. Sordi (ed.), Guerra e diritto nel mondo greco e romano, Milano: 217-227.

Drogula, F. K. (2011), Controlling Travel: Deportation, Islands and the Regulation of Senatorial Mobility in the Augustan Principate, CQ 61/1: 230-266.

Fedeli, P. (ed.) (1980), Sesto Properzio, Il primo libro delle Elegie, Firenze.

Fowler, R. L. (1988), AIГ - in Early Greek Language and Myth, Phoenix 42/2: 95-113.

Francis, C. (2010), Martial, Epigrammata Book X: A Commentary, Dunedin (PhD Thesis).

Freely, J. (2006), Cyclades: Discovering the Greek Islands of the Aegean, London-New York.

Gaertner, J. F. (ed.) (2007), Writing Exile: The Discourse of Displacement in Greco-Roman Antiquity and Beyond, Leiden-Boston.

Goodyear, F. R. D. (1981), The Annals of Tacitus: Books 1-6, vol. II: Annals 1,55-81 and Annals 2, Cambridge.

Guerin-Beauvois, M. (2008), La relégation dans les îles: un espace repensé par les intellectuels exilés, in: P. Blaudeau (ed.), Exil et relégation. Les tribulations du sage et du saint durant l'Antiquité romaine et chrétienne (I ${ }^{e r}-V I^{e}$ S. ap. J.-C.). Actes du colloque organisé par le Centre Jean-Charles Picard, Université de Paris XII-Val de Marne (17-18 juin 2005), Paris: 191-215.

Hardie, A. (1983), Statius and Silvae: Poets, Patrons and Epideixis in the Graeco-Roman World, Liverpool.

Henderson, J. (1991), The Maculate Muse: Obscene Language in Attic Comedy, New York-Oxford.

Kelly, G. P. (2012), A History of Exile in the Roman Republic, Cambridge.

Komar, P. (2014a), Greek Wines for the Roman Elite - in Search of Eastern Luxuries on Western Tables, Eos 2: 227-244.

Komar, P. (2014b), The Consumption of Aegean Wines in Roman Tyrrhenian Italy: between Literary and Archaeological Evidence, Food \& History 12/3: 99-131.

Luck, G. (1977), P. Ovidius Naso, Tristis, Bd. II: Kommentar, Heidelberg.

Maltby, R. (ed.) (2002), Tibullus, Elegies, Cambridge.

Manioti, N. (2017), The View from the Island: Isolation, Exile and the Ariadne Myth, in: J. Velaza (ed.), Insularity, Identity and Epigraphy in the Roman World, Newcastle: 45-67.

Martin, R. (ed.) (2001), Tacitus, Annals V \& VI, Warminster.

Mayer, R. (ed.) (1994), Horace, Epistles: Book I, Cambridge.

Melo, W. D. C. de (2019), Varro, De lingua Latina, vol. II: Commentary, Oxford 2019.

Murgatroyd, P. (1980), Tibullus I: A Commentary on the First Book of the Elegies of Albius Tibullus, Pietermaritzburg.

Myers, K. S. (2000), 'Miranda Fides': Poet and Patrons in Paradoxographical Landscapes in Statius' Silvae, $M D$ 44: 103-138.

Newlands, C. E. (2002), Statius' Silvae and the Poetics of Empire, Cambridge.

Oliveira, F. (2017), The Islands in Pliny the Elder's Work: nuda nomina, in: J. Velaza (ed.), Insularity, Identity and Epigraphy in the Roman World, Newcastle: 25-44.

Paratore, E. (1933), Il Satyricon di Petronio. Parte seconda: Commento, Firenze.

Pawlak, M. N. (2016), From Independence to Dependence: The Administrative Status of the Aegean Islands from $129 \mathrm{BC}$ to $294 \mathrm{AD}$, Electrum 23: 187-214.

Putnam, M. C. J. (1973), Tibullus: A Commentary, Norman. 
Rapske, B. M. (2013), Exiles, Islands, and the Identity and Perspective of John in Revelation, in: S. E. Porter, A. W. Pitts (eds.), Christian Origins and Greco-Roman Culture: Social and Literary Contexts for the New Testament, vol. I: Early Christianity in Its Hellenistic Context, Leiden: 311-346.

Rauch, N. K. (1993), The Sacred Bonds of Commerce: Religion, Economy and Trade Society at Hellenistic Roman Delos, 166-87 B. C., Amsterdam.

Richardson, L. (ed.) (2006), Propertius, Elegies I-IV, Norman.

Rivière, Y. (2008), L'interdictio aqua et igni et la deportatio sous le Haut-Empire romain, in: P. Blaudeau (ed.), Exil et relégation. Les tribulations du sage et du saint durant l'Antiquité romaine et chrétienne (I ${ }^{e r}-V I^{e}$ s. ap. J.-C.). Actes du colloque organisé par le Centre Jean-Charles Picard, Université de Paris XII-Val de Marne (17-18 juin 2005), Paris: 47-113.

Santalucia, B. (2004), La situazione patrimoniale dei deportati in insulam, in: D. Vaillancourt et al. (eds.), Carcer II. Prison et privation de liberté dans l'Empire romain et l'Occident médiéval. Actes du colloque de Strasbourg (décembre 2000), Paris: 9-19.

Schmeling, G. (2011), A Commentary on The Satyrica of Petronius, Oxford.

Seaman, W. M. (1954), The Understanding of Greek by Plautus' Audience, CJ 50: 115-119.

Smith, M. S. (ed.) (1975), Petronii Arbitri: Cena Trimalchionis, Oxford.

Starr, C. G. (1949), Epictetus and the Tyrant, CPh 44/1: 20-29.

Van der Horst, P. W. (ed.) (2003), Philo of Alexandria, Philo's Flaccus, The First Pogrom, LeidenBoston.

Vout, C. (2003), Embracing Egypt, in: C. Edwards, G. Woolf (eds.), Rome the Cosmopolis, Cambridge: 177-202.

Watson, L., Watson P. (eds.) (2003), Martial Select Epigrams, Cambridge.

Watson, L., Watson P. (eds.) (2014), Juvenal, Satire 6, Cambridge.

Weller, J. A. (1958), Tacitus and Tiberius' Rhodian Exile, Phoenix 12/1: 31-35.

West, D. (ed.) (1998), Horace Odes II: Vatis Amici, Oxford.

Woodman, A. J., Martin R. H. (eds.) (1996), The Annals of Tacitus: Book 3, Cambridge.

Zarmakoupi, M. (2015), Hellenistic \& Roman Delos: The City \& Its Emporion, AR 61: 115-132. 